\title{
Origin of Anthropoidea: Dental Evidence and Recognition of Early Anthropoids in the Fossil Record, With Comments on the Asian Anthropoid Radiation
}

\author{
Gregg F. Gunnell ${ }^{1 *}$ AND Ellen R. Miller ${ }^{2}$ \\ ${ }^{1}$ Museum of Paleontology, University of Michigan, Ann Arbor, Michigan 48109-1079 \\ ${ }^{2}$ Department of Anthropology, University of California at Los Angeles, Los Angeles, California 90095 \\ KEY WORDS Eocene primates; Propliopithecidae; Parapithecidae; Tarsiiformes
}

\begin{abstract}
Among the earliest fossil anthropoid primates known are Catopithecus browni, Serapia eocaena, Arsinoea kallimos, and Proteopithecus sylviae, from the late Eocene quarry L-41, Fayum Depression, Egypt. Two of these taxa, $C$. browni and $S$. eocaena, may be the oldest known members of the Propliopithecidae and Parapithecidae, respectively, while $A$. kallimos and $P$. sylviae are archaic anthropoids of less certain familial affiliation. Dental features of $C$. browni, S. eocaena, A. kallimos, and $P$. sylviae are compared with those of younger propliopithecids and parapithecids from the Fayum in order to determine the morphocline polarities of dental features among these early anthropoids. From this, a basal African anthropoid dental morphotype is constructed. Among the features of this morphotype are: dental formula of 2.1.3.3; incisors subvertically implanted and somewhat spatulate; p2 as large as p3, both lacking paraconids; p4 weakly obliquely oriented but not exodaenodont; all lower molars with small paraconids present; upper anterior premolars
\end{abstract}

Over the past decade, many new anthropoid and anthropoid-like primates (= Anthropoidea, simians, including apes, humans, and monkeys) have been discovered from Eocene localities in North Africa, Arabia, and southeastern Asia. Some of these species are known from a substantial amount of material including dental, cranial, and postcranial remains. Others are represented by more fragmentary material, making it difficult to interpret whether the specimens are of an early anthropoid or a prosimian primate that may be anthropoid-like in some respects. This problem is compounded by the fact that as more and earlier anthropoid fossils are described, the morphological gap between anthropoid primates and contemporary prosimian primates narrows.

The purpose of this paper is to outline the dental features that distinguish the Egyptian Fayum anthropoids, to develop an ancestral morphotype based on these taxa, and to compare this morphotype with other, less well-represented, proposed basal anthropoids in order to evaluate the likelihood of possible ancestral-descendant relationships based on dental evidence. We are concerned here specifically with lacking protocone; upper molars with small, cingular hypocones, all cheek teeth nonbunodont; and canines projecting but not necessarily sexually dimorphic.

Comparisons are made between this African anthropoid morphotype and two of the best-represented proposed basal anthropoids, Eosimias and Djebelemur, with the result that neither appears to be a good candidate to have been ancestral to the African anthropoids. Other possible basal simians such as Algeripithecus, Tabelia, and Biretia also are evaluated but are too poorly known for adequate analysis. The larger-bodied Asian primates Pondaungia, Amphipithecus, and Siamopithecus also are not likely ancestors for African anthropoids, but like Eosimias they may share a common ancestry. Despite many recent claims of an Asian origin for anthropoids, the evidence remains far from compelling. The true origins of Anthropoidea remain obscure. Am J Phys Anthropol 114: 177-191, $2001 . \quad$ ๑ 2001 Wiley-Liss, Inc.

possible relationships between other proposed anthropoids and the well-known anthropoids from the Fayum. Other recent attempts at reconstructing an anthropoid hypothetical ancestor (Kay and Williams, 1994; Ross et al., 1998) relied on a computergenerated parsimony analysis of fossil and extant primate species. Our approach is more restricted, as it concentrates only on early fossil anthropoid material from the Eocene and Oligocene.

\section{MATERIALS AND METHODS}

\section{Abbreviations}

An upper case letter denotes a tooth in the maxillary series; a lower case letter denotes a tooth in the mandibular series. For example, M2 is an upper second molar and p2 is a lower second premolar. Institutional abbreviations are as follows: AMNH,

\footnotetext{
*Correspondence to: Dr. Gregg F. Gunnell, Museum of Paleontology, University of Michigan, Ann Arbor, MI 48109-1079.

E-mail: ggunnell@umich.edu
}

Received 16 February 1999; accepted 19 November 2000. 
American Museum of Natural History, New York, NY; CBI, Chambi, Tunisia, specimens housed at the Office National des Mines (Tunis); CGM, Cairo Geological Museum, Cairo, Egypt; CM, Carnegie Museum of Natural History, Pittsburgh, PA; DPC, Duke University Primate Center, Durham, NC; GZC, Glib Zegdou, Algeria specimens, housed in the Oran University collections, Oran-Es Sénia, Algeria; IVPP, Institute of Vertebrate Paleontology and $\mathrm{Pa}$ leoanthropology, Beijing, People's Republic of China; MCZ, Museum of Comparative Zoology, Harvard University, Cambridge, MA; UM, Museum of Paleontology, University of Michigan, Ann Arbor, MI; USGS, United States Geological Survey, Denver, CO; and USNM, United States National Museum, Washington, DC.

\section{Morphotype reconstruction}

Dental character states present in our African anthropoid ancestral morphotype are constructed from features identified in the best-preserved early anthropoids known anywhere in the world. These specimens come from the Fayum Depression, Egypt, where dental remains are associated with skulls (Rasmussen and Simons, 1992; Simons, 1990, 1995a; Simons and Rasmussen, 1996; Simons et al., 1994) and postcrania (Fleagle and Simons, 1982a,b, 1983, 1995; Gebo, 1993; Seiffert et al., 2000). Figure 1 presents a simplified stratigraphic diagram of Fayum fossil localities, showing the location and probable affiliation of taxa used to construct an anthropoid morphotype.

Fayum locality 41 (L-41) in the lower part of the Jebel Qatrani Formation (late Eocene) has yielded the remains of five anthropoid taxa: Catopithecus browni, Proteopithecus sylviae, Serapia eocaena, Arsinoea kallimos, and Qatrania sp. (Miller and Simons, 1997; Simons, 1989, 1992). More specifically, Catopithecus is a probable oligopithecine propliopithecid, Serapia and an undescribed species of Qatrania are parapithecids (but see Ross et al., 1998), and Proteopithecus and Arsinoea are anthropoids of uncertain familial affiliation. The array of anthropoid primates recovered from L- 41 documents a diverse radiation of late Eocene forms, as well as the fact that both major primate families (Propliopithecidae and Parapithecidae) known from the upper part of the Jebel Qatrani Formation (Oligocene) apparently already were present by the late Eocene.

Catopithecus and Proteopithecus are identified as anthropoids because they have advanced cranial features seen in higher primates such as complete postorbital closure, a fused metopic suture, a lacrimal bone enclosed within the orbit, and an ectotympanic annulus fused into the lateral bullar wall (Rasmussen and Simons, 1992; Simons, 1997b). In addition, Catopithecus shares with Oligopithecus and other propliopithecids: 1) loss of P2/p2 (dental formula 2.1.2.3); 2) p3 as long as p4; 3) p3 buccolingually narrow and blade-like, with an anterior wear facet produced by honing with the upper canine; and 4) lower molars with reduced or absent paraconids. Serapia eocaena is assumed to be an anthropoid, even though its taxonomic status is not documented by cranial evidence because of a close morphological relationship in dental structure between L-41 material and parapithecid anthropoids recovered from younger sediments in the Jebel Qatrani Formation. For example, Serapia shares with Parapithecus, Qatrania, and Apidium from Quarry I (Oligocene) a number of primitive features (dental formula 2.1.3.3, premolariform $\mathrm{p} 3$ ), as well as derived character states such as buccally distended canines and premolars and relatively bunodont teeth. The familial affinities of Proteopithecus and Arsinoea are unclear at present, and both taxa may be distinct enough to belong in their own families (Miller and Simons, 1997; Simons, 1992).

Catopithecus and Serapia are here recognized as the earliest known members of the Propliopithecidae and Parapithecidae, respectively, even though both taxa differ from their later occurring relatives in several ways. Catopithecus differs from Oligopithecus in being smaller and in having a relatively less elongate $\mathrm{p} 3, \mathrm{p} 4$ relatively less reduced with a relatively smaller talonid, and P3 with a smaller, more distally placed protocone. Serapia differs from more derived and later-occurring parapithecids in lacking extreme cheek tooth bunodonty, in lacking proliferation of lower molar cuspules (especially true of Qatrania and Apidium), in having more distinct lower molar paraconids, and in having p2 larger than p3: a condition seen in some fossil platyrrhines (e.g., Soriacebus) and some parapithecids (e.g., Parapithecus fraasi, Apidium moustafai) but not in others.

If, as is generally accepted, Anthropoidea is monophyletic, it follows that propliopithecids and parapithecids share a common ancestry. Therefore, we constructed a hypothetical branching sequence that reflects these relationships (Fig. 2): 1) from Catopithecus to Oligopithecus and other stratigraphically younger propliopithecids; 2) from Serapia to younger parapithecids; and 3) with Proteopithecus and Arsinoea as sister taxa to these clades. Using this proposed phylogeny, we traced character state changes from the most derived taxa to the least derived taxa. From this, using commonality, outgroup comparisons with Teilhardina, and a philosophy of minimal assumption, we constructed an African anthropoid morphotype (Table 1).

\section{RESULTS AND COMPARISONS}

We predict that the common ancestor of propliopithecids, parapithecids, Proteopithecus, and Arsinoea possessed the following dental character states (see Table 1 for steps utilized in morphotype reconstruction, Table 2 for complete character list, and Table 3 for character matrix): dental formula of 2.1.3.3; upper and lower incisors small, subvertical, and incipiently spatulate; nonbunodont cheek teeth; 


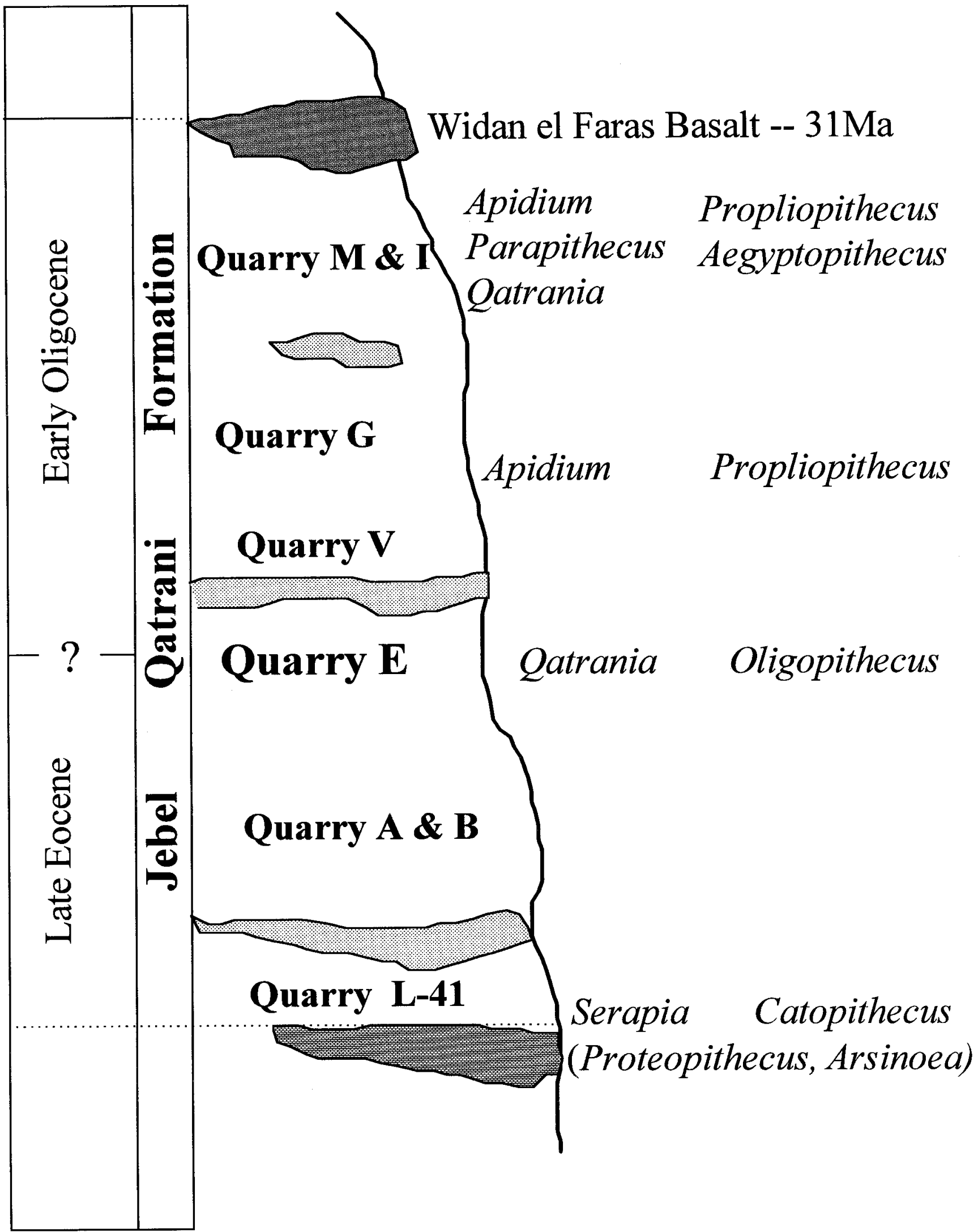

Fig. 1. Relative stratigraphic position of Fayum anthropoid taxa in the Jebel Qatrani Formation and distribution of Fayum quarries. Parapithecidae include Serapia, Qatrania, Apidium, and Parapithecus. Propliopithecidae include Catopithecus, Oligopithecus, Propliopithecus, and Aegyptopithecus. Family level taxonomy of Proteopithecus and Arsinoea (in parentheses) remains unclear (figure modified from Simons, 1995b). 
Parapithecidae (Apidium, Parapithecus, Qatrania)

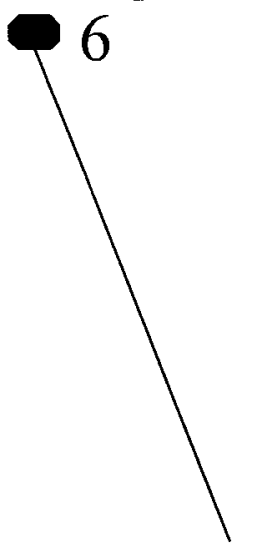

Propliopithecidae (Propliopithecus, Aegyptopithecus,

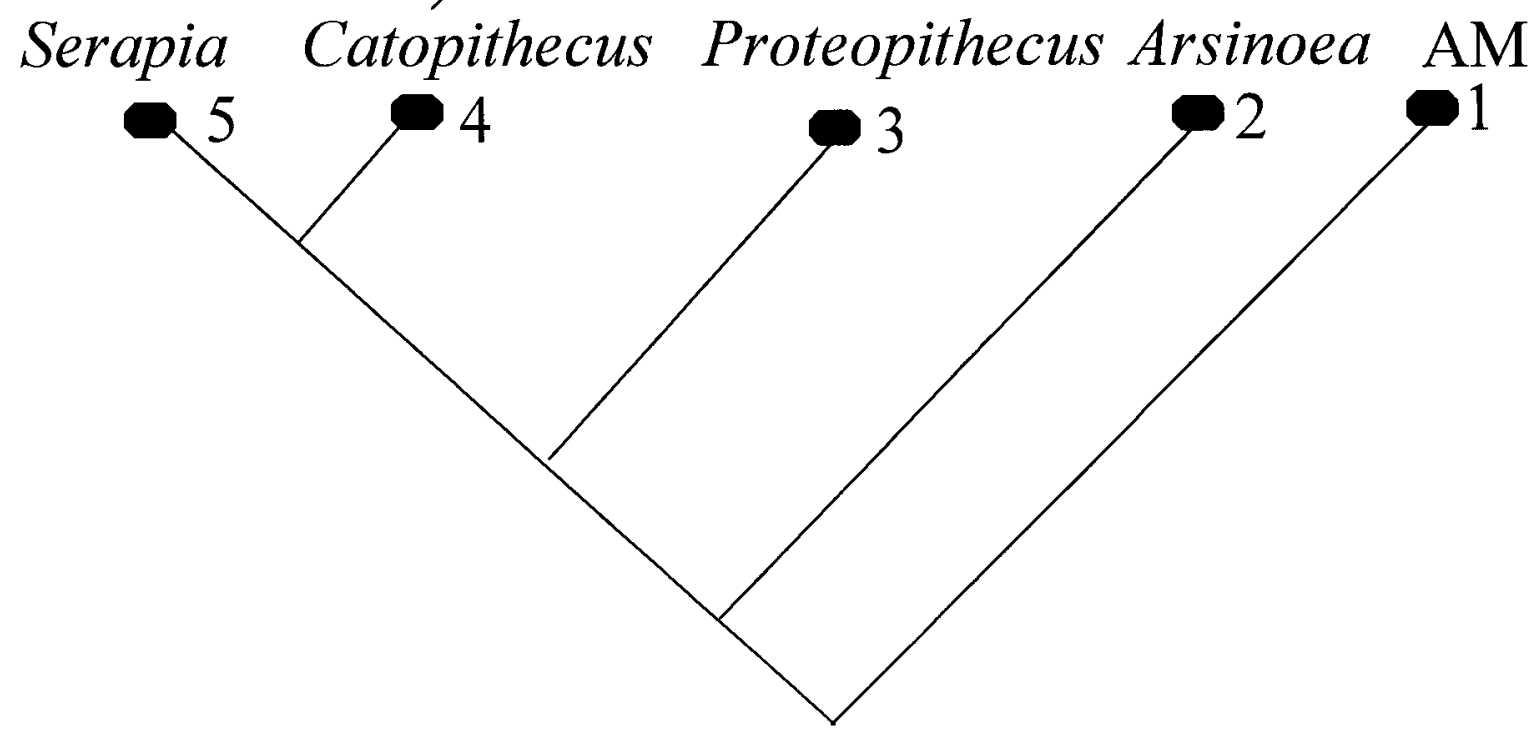

Fig. 2. Hypothetical branching sequence employed in tracing character states for Fayum Anthropoidea (see Table 1).

anterior upper premolars with either small or absent protocones; upper molars with relatively small, cingular (true) hypocones; upper molars with small paraconules and metaconules; canines at least slightly projecting but not necessarily sexually dimorphic; p2 as large as p3; p4 not buccally distended but oriented slightly oblique to the cheek tooth row; p3 premolariform; p4 with distolingually placed, relatively low metaconid, not connected to the protoconid by a crest; p4 semimolariform; all lower molars with small paraconids; m1-2 heterodont; lower molar premetacristids small; lower molar protoconids and metaconids of approximately equal height; m1-2 with relatively small, lingually positioned hypoconulids (perhaps a twinned entoconidhypoconulid); molar accessory cuspules absent; m3 reduced in size compared to $\mathrm{m} 2$; and mandibular symphysis relatively deep.

Figures 3 and 4 compare the lower dentitions of Catopithecus (DPC 12708), Serapia (CGM 42286), Proteopithecus (CGM 42209), and Arsinoea (CGM
42310) with that of Eosimias centennicus (IVPP V11000) from the late middle Eocene Heti Formation of east-central China (Beard et al., 1996) and Djebelemur martinezi (CBI 33, Fig. 3 only) from the early-middle Eocene locality of Chambi, Tunisia (Hartenberger and Marandat, 1992).

Eosimias shares several features in common with the reconstructed African morphotype, including (Table 2 character number in parentheses): a dental formula of 2.1.3.3; projecting canine (5); p4 oblique, not exodaenodont (7); premolariform p3 (8); low, distolingually positioned metaconid on p4 (9); semimolariform p/4 (10); nonbunodont cheek teeth (11); small molar premetacristids (14); lack of molar accessory cuspules (17); and a relatively deep symphysis (22). However, few of these character states likely demonstrate a special relationship between Eosimias and African anthropoids to the exclusion of many prosimian-like adapiforms and omomyids. A lower dental formula of 2.1.3.3 occurs in both omomyids and some adapiforms (Aframonius, Cercamo- 
TABLE 1A. Ancestral morphotype reconstruction: derived nodal characters $^{1}$

Node 7: p3-4 exodaenodont, oblique (7-3); cheek teeth bunodont $\left(11-1^{2}\right)$; paraconids absent on all lower molars (13$\left.4^{2,3}\right)$; upper molars with large hypocone $\left(19-2^{2}\right)$; mandibular symphysis deep, buttressed, fused $\left(22-3^{2,3}\right)$

Node 6: Paraconids absent on all lower molars $\left(13-4^{2,3}\right)$; lower molar accessory cusps present (17-1); upper molars with large para- and metaconules (20-3); mandibular symphysis deep, buttressed, fused $\left(22-3^{2}\right)$

Node 5: p3-4 exodaenodont, not oblique (7-2 $\left.{ }^{3}\right)$; p4 metaconid intermediate, lingual, not connected to protoconid $\left(9-1^{3}\right)$; cheek teeth bunodont $\left(11-1^{2}\right)$

Node 4: Incisors large, vertical, fully spatulate (4-2); canines projecting, dimorphic, honing (5-2); P2/p2 absent (6-4); p3 narrow, blade-like, hones against upper canine $\left(8-2^{2}\right)$.

Node 3: p2 larger than p3 (6-2); m1-2 heterodont (12-1); molar paraconids reduced, usually absent on m2-3 (13-1); small protocone present on anterior upper premolars $\left(18-1^{3}\right)$; upper molars with small, cingular hypocones (19-1)

Node 2: Incisors subvertical, incipiently spatulate $\left(4-1^{2,3}\right) ; \mathrm{p} 2$ as large as p3 (6-1); p3-4 exodaenodont, oblique $\left(7-3^{2,3}\right) ; \mathrm{p} 4$ semimolariform (10-1); lower molar premetacristids small but present (14-1); protoconid taller than metaconid (15-12); m1-2 hypoconulids lingual, twinned (16-1); m3 reduced (211); mandibular symphysis deep (22-1)

${ }^{1}$ Character states shared by nodal taxon and subsequent descendant taxa to the exclusion of ancestral morphotype and other African anthropoid clades; character number and state in parentheses.

${ }^{2}$ Indicates homoplasic character state.

${ }^{3}$ Indicates character state not shared by all members of clade.

nius, Mahgarita, Caenopitheus) and is primitive for anthropoids (Gingerich, 1977). Nonbunodont cheek teeth and a distolingually placed $\mathrm{p} 4$ metaconid are also common features among both prosimian groups and are likely primitive conditions for anthropoids, as is the lack of lower molar accessory cuspules. Semimolariform lower fourth premolars are also common in many prosimian groups. A relatively deep mandibular symphysis may represent a shared, derived character of Eosimias and our African morphotype, but could just as easily represent homoplasy. Modern tarsiers have a mandible that deepens towards the symphysis, the result of a loss of one pair of incisors and an enlarged canine.

The issue of incisor implantation angle (character 4) has received a great deal of discussion (Gingerich, 1977; Beard et al., 1996; Rose et al., 1999). Subvertically implanted incisors are usually present in adapiforms (Gingerich, 1977, but see Rose et al., 1999), occur occasionally among omomyids (Covert and Williams, 1991; Gingerich, 1977), and are the primitive condition for anthropoids as reconstructed here (see also Ross et al., 1998). In an attempt to assess the distribution and extent of incisor angle implantation among fossil primates, we examined a number of taxa that preserve lower incisors. We made camera lucida drawings in lateral view of these taxa, and then drew a horizontal line parallel to the base of the first lower molar. We then drew a line through the center of i2 (i2 was chosen because it is more often preserved than i1) parallel to the long axis of the tooth. We then measured the angle formed by the intersection of these two lines, with a higher angle representing a more vertical incisor. The results are presented in Table 4 .

Table 4 shows that, in general, tarsiiforms have relatively low incisor implantation angles (ranging from $41-53^{\circ}$ ), resulting in relatively procumbent incisors. Adapiforms exhibit a wide range of incisor implantation, ranging from very procumbent $\left(35^{\circ}\right)$ to quite vertical $\left(71^{\circ}\right)$. It is interesting to note that, at least in the case of Notharctus tenebrosus, incisor angle seems to be correlated with sex, with the male having a high angle and the female having a lower angle of incisor implantation. This suggests that, at least for some sexually dimorphic adapiforms, incisor angle may depend more on canine and symphysial ontogenetic development, and as such may not be a useful phylogenetic characteristic. Fayum anthropoids have relatively high incisor implantation angles $\left(65-68^{\circ}\right)$ that are overall more similar to adapiforms than to tarsiiforms. Eosimias has a very high angle of incisor implantation $\left(86^{\circ}\right)$ and thus seems not to resemble any of the other primates examined here.

The morphology of Eosimias incisors appears unique as well. As noted, the incisors of Eosimias are extremely vertically implanted and, in addition, they are very tiny. The incisor roots are of a larger caliber than the crowns, a feature not observed by us in any other primates we examined (except for a few omomyids). Instead of being interpreted as prespatulate precursors of the enlarged, spatulate incisors of anthropoids, the incisors of Eosimias could just as easily be interpreted as being in the process of being reduced, with the deepened symphysis resulting from the shortening of the anterior portion of the mandible and the enlargement of the canine.

In addition, Eosimias exhibits a number of derived character states that seem incongruous with our proposed African anthropoid ancestral condition. Eosimias has a large, projecting canine as does our Fayum anthropoid morphotype (FAM), but the apex of the canine is recurved posteriorly, a feature not seen among early anthropoids. The p2 of Eosimias is small relative to the size of $\mathrm{p} 3$, while in our FAM p2 is as large as p3 and, in fact, p2 is larger than p3 in some parapithecids and in some fossil platyrrhines (e.g., Soriacebus; see Fleagle, 1990; Fleagle et al., 1987). Beard et al. (1996, p. 83) noted that Eosimias "differs from many other basal anthropoids [for example, Arsinoea, Serapia, and many platyrrhines]" in having a diminutive $\mathrm{p} 2$. These authors noted that it is unclear whether the small size of the p2 of Eosimias is primitive or derived with respect to other basal anthropoids.

Comparisons of Eosimias centennicus with Eosimias sinensis suggest that p2 size through the Eosimias lineage is being reduced. $E$. sinensis was described from the Shanghuang fissures (Beard et al., 1994), while $E$. centennicus is from the Heti Formation in the Yuanqu Basin in China. Beard et al. 
TABLE 1B. Ancestral morphotype for Fayum anthropoids (character number and assigned state in parentheses)

Character state

PO Closure complete (1-1)

Metopic suture fused (2-1)

Lacrimal foramen within orbit (3-1)

Incisors small, subvertical, incipiently spatulate (4-1)

Canines projecting, not dimorphic (5-0)

p2 as large as p3 (6-1)

p4 oblique, not exodaenodont (7-1)

p3 premolariform (8-0)

p4 metaconid low, not connected to protoconid (9-0)

p4 semimolariform (10-1)

Cheek teeth nonbunodont (11-0)

m1-2 heterodont with paraconid (12-0)

Molar paraconids small, present on all molars (13-0)

Molar premetacristids small (14-0)

Protoconid-metaconid equal in height (15-0)

m1-2 hypoconulids lingual/twinned (16-1)

Molar accessory cusps absent (17-0)

Upper anterior premolars lacking protocone (18-0)

Upper molars with small, cingular hypocone (19-1)

Paraconule and metaconule small (20-0)

m3 reduced (21-1)

Deep mandibular symphysis (22-1)

Reason for assignment

Shared by all known forms

Shared by all known forms

Shared by all known forms

Known forms share or have more derived condition Primitive condition, shared by most primitive taxon Known forms share or have more derived condition

Known forms share or have more derived condition Primitive condition of outgroup

Primitive condition, shared by most primitive taxon Known forms share or have more derived condition Primitive condition, shared by most primitive taxon Primitive condition, shared by most primitive taxon Primitive condition, shared by most primitive taxon Known forms share or have more derived condition ${ }^{1}$ Primitive condition of outgroup

Known forms share or have more derived condition ${ }^{2}$ Primitive condition, shared by most primitive taxon Primitive condition of outgroup

Known forms share or have more derived condition Primitive condition of outgroup

Primitive condition, shared by most primitive taxon Known forms share or have more derived condition

${ }^{1}$ Qatrania and Oligopithecus lack distinct premetacristids, coded as primitive but probably secondarily derived.

${ }^{2}$ Apidium, Propliopithecus, and Aegyptopithecus have small, centered hypoconulids, coded as primitive but probably secondarily derived.

(1996) noted that E. centennicus is somewhat younger in age than its Shanghuang counterpart. An examination of the holotype of $E$. sinensis (IVPP 10591) reveals that, unlike $E$. centennicus, this taxon had a relatively larger, single-rooted p2 that was not separated from the lower canine and p3 by diastemata as it is in $E$. centennicus. This suggests to us that the derived condition in Eosimias is that of a very reduced $\mathrm{p} 2$, probably in the process of being lost or at least becoming functionally unimportant. This is in contrast to the condition seen in the most primitive Fayum anthropoids.

Lower p4 of Eosimias has an anterior root that is positioned slightly buccal to the posterior root, making $\mathrm{p} 4$ slightly oblique to the cheek tooth row. The buccal surface of the anterior root is extended down towards the gingival surface of the mandible. The former character state is shared in common with our FAM as well as with Proteopithecus, Catopithecus, and Bahinia, and may represent an anthropoid synapomorphy, although the occurrence of obliquely oriented premolars in some notharctines and plesiadapiform microsyopids weakens the strength of this possible synapomorphy.

The issue of $\mathrm{p} 4$ exodaenodonty and buccal distention in various anthropoid and basal anthropoid taxa is another area where opinions differ (Beard et al., 1996). Our definition of $\mathrm{p} 4$ exodaenodonty is a tooth that is buccally enlarged, such that $\mathrm{p} 4$ is as wide as or wider than it is long, often with the tooth extending laterally at least to the lateral margin of the horizontal ramus of the mandible and down beyond the gingival margin of the mandible (as in traditionally recognized exodaenodont omomyids such as Uintanius and some species of Absarokius; see Bown and Rose, 1987; Gunnell, 1995). Figure 5 presents the results of a quantification of the length and width of $\mathrm{p} 4$ for a number of primate taxa. Of the primate taxa examined, several Fayum anthropoids and the omomyid Uintanius all have p4 wider than long. Eosimias resembles the prosimian taxa Teilhardina and Cantius in having $\mathrm{p} 4$ much longer than wide.

Figure 6 presents two other representations of $\mathrm{p} 4$ exodaenodonty. Figure $6 \mathrm{~A}$ is a simple bivariate plot of p4 length vs. width, showing that Eosimias groups with Teilhardina and differs from nearly all Fayum anthropoids except Catopithecus, which also has a p4 longer than wide. Figure $6 \mathrm{~B}$ compares $\mathrm{p} 4$ width vs. mandibular width and also shows the outlying position of Eosimias compared to most Fayum anthropoids (and some prosimian taxa as well). While Eosimias does have a slight buccal distention of the anterior root of $\mathrm{p} 4$, it is clear from these comparisons that it differs substantially from the type of exodaenodonty exhibited by Fayum anthropoids.

In the lower molar series, Eosimias has large and mesially projecting paraconids on $\mathrm{m} 1-\mathrm{m} 3$ that are separated from the metaconids by deep, sharply defined valleys. The presence of paraconids might be interpreted as a primate symplesiomorphy, but the prominence and mesial thrust of the paraconids in Eosimias make them appear to be a derived rather than primitive feature. In addition, few other Paleogene primates (noted exceptions being the tarsiiforms Macrotarsius and Afrotarsius) and no African anthropoids have comparable molar paraconids. When they occur in early anthropoids, paraconids tend to be much reduced in size and retained only on $\mathrm{m} 1$ or occasionally on $\mathrm{m} 1$ and $\mathrm{m} 2$. Our reconstructed 
TABLE 2. Anthropoid craniodental character list with discussion of polarity determination (Omomyidae and Adapiformes used as outgroups)

1) Postorbital closure: absent (0); complete (1). Outgroup comparison indicates the primitive primate condition is absence of postorbital closure.

2) Metopic suture: open (0); fused (1). Outgroup comparison indicates the primitive primate condition is an unfused metopic suture.

3) Lacrimal foramen: outside orbit (0); within orbit (1). Outgroup comparison indicates the primitive primate condition is having lacrimal foramen outside orbit.

4) Incisors: incisiform (0), small, subvertical, incipiently spatulate (1); larger, vertical, spatulate (2). Outgroup comparison equivocal: comparison with more primitive mammals suggests that incisiform, subvertical incisors are probably primitive for primates (See Table 4).

5) Canines: projecting, not dimorphic (0); not projecting, (1); projecting, honing, dimorphic (2). Outgroup comparison equivocal: comparison with more primitive mammals suggests that projecting, nondimorphic canines are the primitive mammalian condition.

6) $\mathrm{p} 2$ : smaller than $\mathrm{p} 3$ (0); as large as p3 (1); larger than p3 (2); reduced (3); absent (4). Outgroup comparison indicates that p2 smaller than $\mathrm{p} 3$ is primitive primate state.

7) p4: not exodaenodont, not obliquely oriented (0); not exodaenodont, oblique (1); exodaenodont; not oblique (2); exodaenodont, oblique (3). Outgroup comparison indicates that the primitive primate condition is to have lower premolars that are neither exodaenodont nor obliquely oriented in the dentary. See Figures 5-6.

8) p3: premolariform (0); semimolariform (1); narrow, blade-like (2). Outgroup comparison indicates that the primitive primate condition is to have p3 premolariform.

9) p4 metaconid: low, distolingual, not connected to protoconid (0); intermediate, lingual, not connected to protoconid (1); higher, lingual, connected to protoconid (2); higher, distolingual, not connected (3). Outgroup comparisons indicate that a low, disconnected metaconid is primitive for primates.

10) $\mathrm{p} 4$ : premolariform (0); semimolariform (1); blade-like (2). Outgroup comparisons indicate that a premolariform $\mathrm{p} 4$ with a weak metaconid is primitive for primates.

11) Cheek teeth: nonbunodont (0); bunodont (1). Outgroup comparisons indicate that primitive primate teeth are nonbunodont.

12) m1-2: heterodont with paraconid (0); heterodont, paraconid reduced to absent (1); homodont without paraconid (1); homodont with paraconid (4). Polarity equivocal. Outgroup comparisons suggest that basal primates have heterodont m1-2.

13) Lower molar paraconids: small, present on all molars (0); small, absent on m2-3 (1); larger, present on all molars (3); absent on all molars (4). Outgroup comparisons indicate that the primitive primate condition is having paraconids on all molars.

14) Lower molar premetacristids: absent (0); small (1); larger, more distinct (2). Premetacristids are absent in primitive primates

15) Lower molar protoconid-metaconid: equal height (0); protoconid taller (1); metaconid taller (2). Outgroup comparisons support this polarity interpretation.

16) m1-2 hypoconulids: centered (0); lingual or twinned (1); absent (2). Outgroup comparisons support this polarity interpretation.

17) Lower molar accessory cusps: absent (0); present (1). Outgroup comparisons support this polarity interpretation.

18) Upper anterior premolars: lacking protocone (0); small protocone present (1). Primitive primates lack protocones on upper anterior premolars.

19) Upper molars: hypocone absent (0); small, cingular hypocone (1); larger hypocone (2). Polarity equivocal. Outgroup comparisons indicate that primitive primates had very weak to absent hypocones on upper molars. Where hypocones exist, they are derived from a postprotocingulum, not posterior cingulum.

20) Upper molars: with small paraconule and metaconule (0); conules absent (1); metaconule only (2); large paraconule and metaconule (3). Small conules appear primitive for primates based on outgroup comparisons.

21) $\mathrm{m} 3$ size: $\mathrm{m} 2=\mathrm{m} 3(0) ; \mathrm{m} 3$ reduced (1). Primitive state for this character appears to be an unreduced $\mathrm{m} 3$.

22) Mandibular symphysis: shallow (0); deep (1); deep, buttressed, unfused (2); deep, buttressed, fused (3). Outgroups have shallow mandibular symphysis.

TABLE 3. Anthropoid craniodental character matrix

\begin{tabular}{|c|c|c|c|c|c|c|c|c|c|c|c|c|c|c|c|c|c|c|c|c|c|c|}
\hline Taxon & 1 & 2 & 3 & 4 & 5 & 6 & 7 & 8 & 9 & 10 & 11 & 12 & 13 & 14 & 15 & 16 & 17 & 18 & 19 & 20 & 21 & 22 \\
\hline Teilhardina & $?$ & $?$ & $?$ & 0 & 1 & 3 & 0 & 0 & 0 & 0 & 0 & 0 & 0 & 0 & 0 & 0 & 0 & 0 & 0 & 0 & 1 & 0 \\
\hline Arsinoea & $?$ & $?$ & $?$ & 1 & 0 & 1 & 3 & 1 & 0 & 1 & 0 & 0 & 0 & 1 & 1 & 1 & 0 & $?$ & $?$ & $?$ & 1 & 1 \\
\hline Proteopithecus & 1 & 1 & 1 & $?$ & 0 & 2 & 1 & 0 & 2 & 1 & 0 & 1 & 1 & 2 & 0 & 1 & 0 & 1 & 1 & 2 & 1 & 1 \\
\hline Serapia & $?$ & $?$ & $?$ & $?$ & 1 & 2 & 2 & 0 & 1 & 1 & 1 & 1 & 1 & 1 & 0 & 1 & 0 & $?$ & $?$ & $?$ & 1 & 1 \\
\hline Qatrania & $?$ & $?$ & $?$ & $?$ & $?$ & 3 & 3 & $?$ & 0 & 1 & 1 & 1 & 1 & 0 & 0 & 1 & 1 & $?$ & $?$ & $?$ & 1 & $?$ \\
\hline Apidium & 1 & 1 & 1 & 2 & 1 & 1 & 2 & 0 & 1 & 1 & 1 & 1 & 4 & 1 & 0 & 0 & 1 & 1 & 2 & 3 & 0 & 3 \\
\hline Catopithecus & 1 & 1 & 1 & 2 & 2 & 4 & 1 & 2 & 2 & 1 & 0 & 1 & 1 & 1 & 0 & 1 & 0 & 0 & 1 & 0 & 1 & 1 \\
\hline Oligopithecus & $?$ & $?$ & $?$ & $?$ & 2 & 4 & 3 & 2 & 2 & 1 & 0 & 1 & 1 & 0 & 0 & 1 & 0 & $?$ & 2 & 2 & $?$ & 1 \\
\hline Propliopithecus & $?$ & $?$ & $?$ & 2 & 2 & 4 & 3 & 2 & 2 & 1 & 1 & 1 & 4 & 2 & 0 & 0 & 0 & 1 & 2 & 1 & 0 & 3 \\
\hline Aegyptopithecus & 1 & 1 & 1 & 2 & 2 & 4 & 3 & 2 & 2 & 1 & 1 & 1 & 4 & 2 & 0 & 0 & 0 & 1 & 2 & 1 & 0 & 3 \\
\hline Eosimias & $?$ & $?$ & $?$ & 3 & 0 & 3 & 1 & 0 & 0 & 1 & 0 & 3 & 3 & 0 & 1 & 0 & 0 & $?$ & $?$ & $?$ & 0 & 1 \\
\hline Bahinia & $?$ & $?$ & $?$ & $?$ & 0 & 3 & 1 & $?$ & 4 & 0 & 0 & $?$ & $?$ & 0 & 1 & 0 & 0 & 0 & 0 & 1 & $?$ & $?$ \\
\hline Afrotarsius & $?$ & $?$ & $?$ & $?$ & $?$ & $?$ & 0 & $?$ & $?$ & 1 & 0 & 3 & 3 & 0 & 1 & 0 & 0 & $?$ & $?$ & $?$ & 0 & $?$ \\
\hline Aframonius & $?$ & $?$ & $?$ & 1 & 0 & 3 & 0 & 0 & 2 & 1 & 0 & 2 & 4 & 0 & 0 & 2 & 0 & 1 & 2 & 0 & 0 & 0 \\
\hline Djebelemur & $?$ & $?$ & $?$ & $?$ & $?$ & $?$ & 0 & 2 & 4 & 2 & 0 & 2 & 4 & 2 & 0 & 2 & 0 & $?$ & $?$ & $?$ & 0 & 0 \\
\hline Siamopithecus & $?$ & $?$ & $?$ & $?$ & $?$ & $?$ & $?$ & $?$ & $?$ & $?$ & 1 & 1 & 1 & 2 & 0 & 0 & 0 & 1 & 2 & 1 & 0 & $?$ \\
\hline Pondaungia & $?$ & $?$ & $?$ & $?$ & $?$ & $?$ & $?$ & $?$ & $?$ & $?$ & 1 & 1 & 1 & 2 & 0 & 2 & 1 & $?$ & 2 & 2 & 0 & $?$ \\
\hline Amphipithecus & $?$ & $?$ & $?$ & 2 & 2 & 3 & 3 & 1 & 2 & 1 & 1 & 1 & 1 & 2 & 0 & 2 & 0 & $?$ & $?$ & $?$ & 1 & 2 \\
\hline
\end{tabular}

ancestor retained paraconids on all lower molars, but they were likely to have been small and more closely appressed to the metaconid.
The lower molars of Eosimias have protoconids that are relatively larger and higher than the metaconids. This feature has been interpreted as either a 


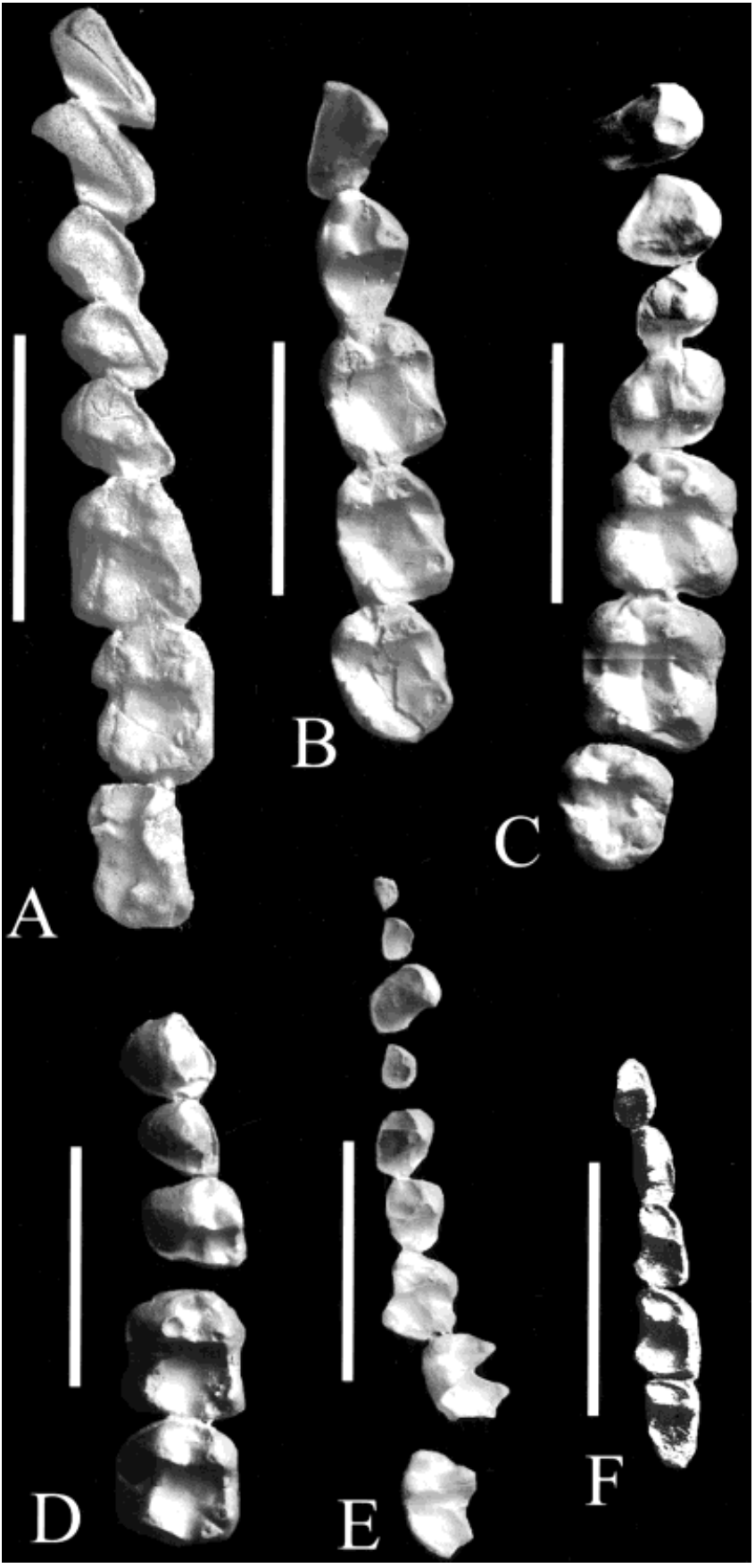

Fig. 3. Scanning electron micrographs in occlusal view. A: Arsinoea callimos, CGM 42310, left dentary with i2-m3. B: $\mathrm{Ca}$ topithecus browni, DPC 12708, right dentary with p3-m3. C: Serapia eocaena, CGM 42286, right dentary with c1-m3. D: Proteopithecus sylviae, CGM 42209, left dentary with p2-m2. E: Eosimias centennicus, IVPP V11000, right dentary with i1-m3. F: Djebelemur martinezi, CBI 33, left dentary with p3-m3. Scale bars represent $5 \mathrm{~mm}$.

primitive primate retention (Godinot, 1994), or an anthropoid synapomorphy (Beard et al., 1994). We see no evidence in the fossil record to suggest that a large and high lower molar protoconid is a derived feature for anthropoids. Nearly all of the taxa included in this study have protoconids and metac-
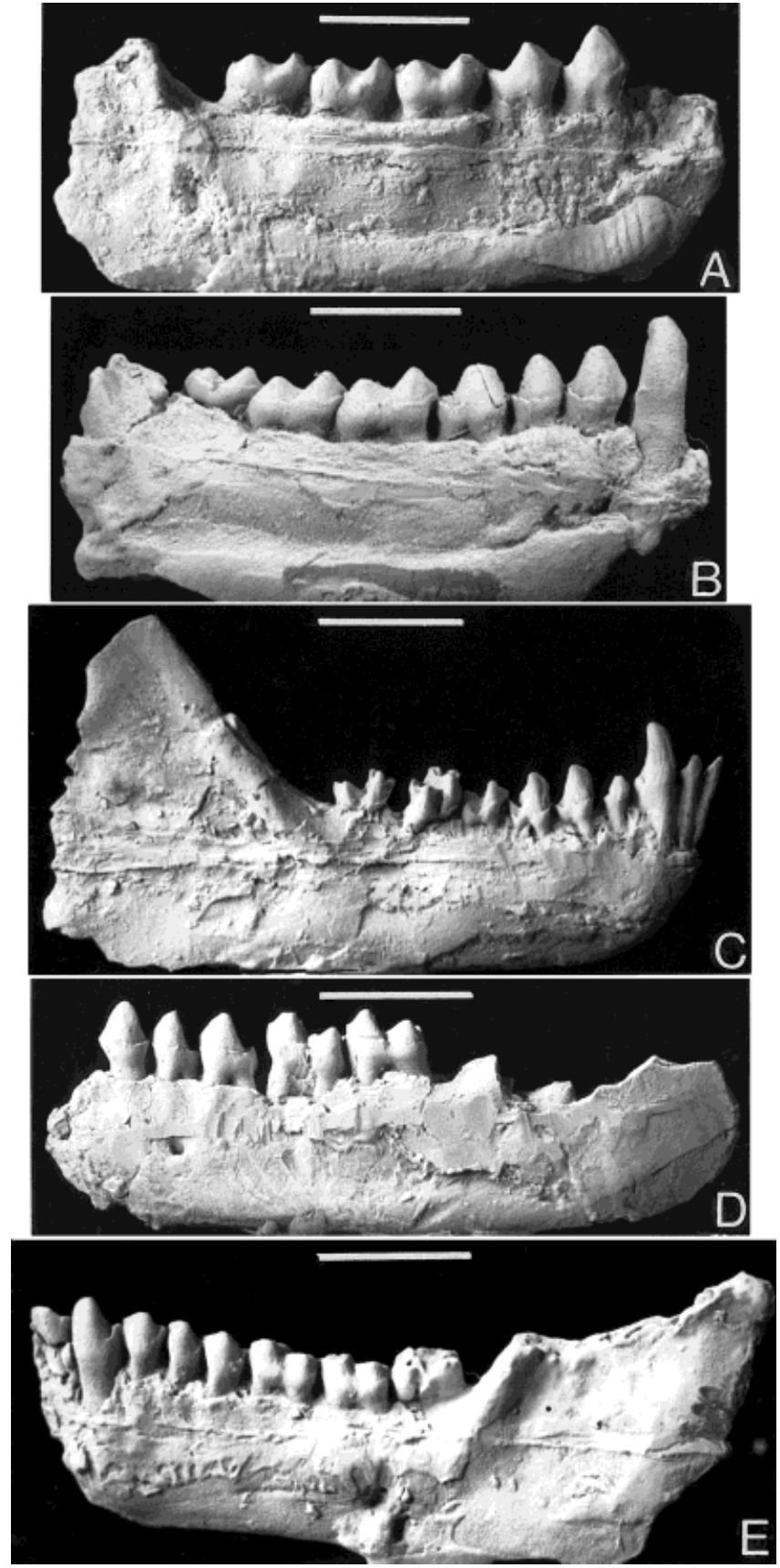

Fig. 4. Lateral views of lower dentitions. A: Catopithecus browni, DPC 12708, right dentary with p3-m3. B: Serapia eocaena, CGM 42286, right dentary with c1-m3. C: Eosimias centennicus, IVPP V11000, right dentary with i1-m3. D: Proteopithecus sylviae, CGM 42209, left dentary with p2-m2. E: Arsinoea callimos, CGM 42310, left dentary with i2-m3. Scale bars represent $5 \mathrm{~mm}$.

onids of equal height (the condition we interpret as primitive). Many of the poorly known possible basal anthropoids from northern Africa and Arabia ( $A l$ geripithecus, Tabelia, and Biretia) have relatively enlarged lower molar metaconids (de Bonis et al., 1988; Godinot and Mahboubi, 1992, 1994). Afrotarsius and Bahinia are the only other taxa in this study that share a higher molar protoconid than metaconid with Eosimias. 
TABLE 4. Primate incisor implantation angle ${ }^{1}$

\begin{tabular}{lc}
\hline Taxon (specimen number in parentheses) & Angle \\
\hline Tarsiiformes & \\
Tarsius sp. & $54^{\circ}$ \\
Washakius insignis (AMNH 55665) & $53^{\circ}$ \\
Teilhardina sp. (USGS 512) & $41^{\circ}$ \\
Tetonius matthewi (CM 12190) & $53^{\circ}$ \\
Pseudotetonius ambiguus (MCZ 19010) & $50^{\circ}$ \\
Adapiformes & \\
Cantius abditus (USNM 494881) & $35^{\circ}$ \\
Cantius abditus (UM 93938) & $61^{\circ}$ \\
Cantius nunienus (AMNH 55157) & $68^{\circ}$ \\
Notharctus tenebrosus (AMNH 131776) & $71^{\circ}$ \\
Notharctus tenebrosus (AMNH 129382) & $36^{\circ}$ \\
Notharctus venticolis (AMNH 14655) & $62^{\circ}$ \\
Smilodectes gracilis (USNM 21815) & $60^{\circ}$ \\
Anthropoidea and ?Anthropoidea & \\
Arsinoea callimos (CGM 42310) & $65^{\circ}$ \\
Catopithecus browni (DPC 7342) & $68^{\circ}$ \\
Aegyptopithecus zeuxis (CGM 40137) & $68^{\circ}$ \\
Eosimias centennicus (IVPP V11000) & $86^{\circ}$ \\
\hline
\end{tabular}

${ }^{1}$ Angle measured is formed by horizontal line drawn through and parallel to base of $\mathrm{m} 1$ and line drawn through and parallel to long axis of $\mathrm{i} 2$.

Eosimias appears distinctly nonanthropoid in a few other features. For example, Eosimias has m1-2 nearly identical in size and morphology. While not completely unknown in primates (some tarsiiforms such as Macrotarsius (Clark, 1941) and Afrotarsius (Simons and Bown, 1985) have nearly identical $\mathrm{m} 1-2$, as do some hominoids), this character state is relatively rare, especially in combination with an enlarged molar paraconid. Some adapiforms, especially adapines and some cercamoniines, have m1-2 homodonty, but always lack a paraconid. Additionally, Eosimias lower molars have a distally extended, centrally placed hypoconulid that is connected to the entoconid by a high, distinct crest. This character state is unknown in anthropoids as far as we are aware, although many anthropoids do have m1-2 hypoconulids in close proximity to entoconids ("twinned").

In the original description of Eosimias, the shortened anterior cheek tooth region was stressed as an important synapomorphy with anthropoids (Beard et al., 1994). The evidence put forth for such shortening was a small, single-rooted p2, a short p3 that is oriented oblique in the jaw, and a relatively mesiodistally short p4. It is true that anthropoids, and in particular oligopithecines and propliopithecines, do have shortened anterior cheek tooth regions, but such shortening was accomplished in a manner different from that documented for Eosimias. The p3 in oligopithecines and propliopithecines is oriented oblique to the cheek tooth row, but it does not become shorter; instead, it becomes narrower and elongate (Rasmussen and Simons, 1988). Lower p4 in oligopithecines and propliopithecines does not get shorter (except perhaps for Propliopithecus haeckeli), but instead simply becomes proportionally smaller and eventually becomes obliquely oriented in the jaw as well (clearly seen in Aegyptopithecus). The fact that Eosimias possesses a slightly obliquely oriented p3 and has a differently derived, shortened anterior cheek tooth region suggests that any resemblances between Eosimias and later Fayum anthropoids in these character states are convergent.

The type specimen of Djebelemur martinezi (CBI 33 , from the early/middle Eocene locality of Chambi, Tunisia, is a left dentary originally described as an adapiform primate (Hartenberger and Marandat, 1992) but subsequently reinterpreted to be a possible anthropoid (Godinot, 1994). Comparisons between the type of $D$. martinezi and our ancestral morphotype show that the two share: a lower dental formula of ?2.1.3.3; nonbunodont cheek teeth (11); lower molar protoconids and metaconids of approximately equal height (15); and the absence of lower molar accessory cuspules (17). All of these shared character states are interpreted as primitive for anthropoids.

Djebelemur differs from the proposed anthropoid condition in a number of key features, especially in having $\mathrm{p} 3-\mathrm{p} 4$ laterally compressed and elongate. In particular, a buccolingually compressed, blade-like p4 is never seen in anthropoids. Djebelemur further differs from the proposed anthropoid morphotype in possessing lower molar trigonids that are closed by a continuous crest formed by the preprotocristid, a strongly developed, transverse paracristid, and an extended premetacristid. Examination of the type mandible of Djebelemur supports the original interpretation of Djebelemur as a derived cercamoniine adapiform. Djebelemur shares with cercamoniine adapids, e.g., Periconodon and Anchomomys, a completely closed, mesially extended, and somewhat skewed molar trigonid, and a relatively narrow and elongate $\mathrm{m} 1$ adjacent to a slightly shorter but broader m2. Djebelemur differs from other small cercamoniines except Wadilemur (Simons, 1997a) in having p3-4 buccolingually compressed.

An isolated M2 (CBI 36) and M3 (CBI 35) have been allocated to Djebelemur sp., but these specimens are problematic (Hartenberger and Marandat, 1992). Both teeth appear somewhat larger and more bunodont than might be expected for the upper molars of Djebelemur, and further evidence is required to assess the taxonomic placement of these specimens.

As for Algeripithecus minutus, Algeripithecus sp., Tabelia hammadae, Tabelia sp., and Biretia piveteaui, all are so poorly represented that it is impossible to be able to interpret the higher systematic placement of these taxa (de Bonis et al., 1988; Godinot, 1994; Godinot and Mahboubi, 1992, 1994). Although the type specimen of Algeripithecus, an M2 (GZC 1), has a cingular hypocone, a feature of our expected morphotype for African anthropoids, this is likely a primitive condition for anthropoids. Not enough additional information is known about $A l$ geripithecus to make more substantial comparisons. Similarly, comparisons between our ancestral morphotype and Altiatlasius koulchii from the late $\mathrm{Pa}-$ leocene of Morocco show that Altiatlasius is simply 


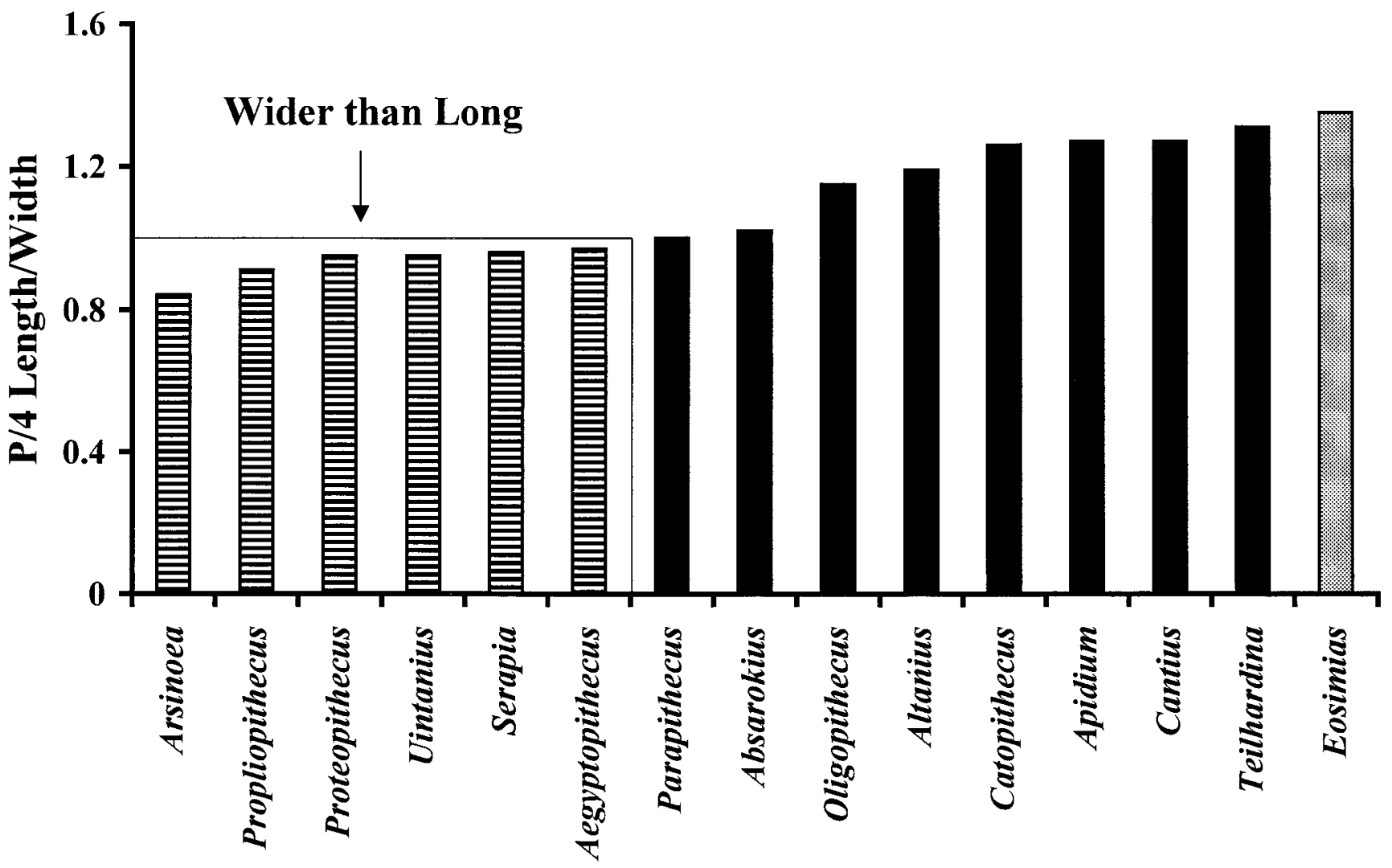

Taxon

Fig. 5. Histograms of $\mathrm{p} 4$ length divided by $\mathrm{p} 4$ width for a variety of omomyid, adapiform, anthropoid taxa. The most highly exodaenodont taxa (p4 wider than long) are indicated by stripes, Eosimias by light shading. Note position of Eosimias as least exodaenodont among all included taxa.

so primitive in all respects that we could not rule it out as a possible anthropoid ancestor (Sigé et al., 1990). Hooker et al. (1999) recently suggested that Altiatlasius may be a plesiadapiform.

The southeast Asian taxa Pondaungia, Amphipithecus, Wailekia, and Siamopithecus have some features that have traditionally been considered anthropoid-like, particularly their large size, bulbous, flat teeth, and a lack of molar paraconids (Chaimanee et al., 1997; Ciochon et al., 1985). Comparisons with our African anthropoid morphotype show some shared character states. Amphipithecus shares a semimolariform p4 (10), lower m1-2 heterodonty (12), lower molar protoconids and metaconids of equal height (15), and a lack of molar accessory cuspules (17). Of these, the last three appear to be primitive for anthropoids, while a semimolariform p4 is typical of most adapiforms and many omomyiforms as well. Pondaungia and Siamopithecus also share lower molar heterodonty, molar proto- and metaconids of equal height, and a lack of molar accessory cuspules with Amphipithecus and our FAM. Siamopithecus shares lingual or twinned m1-2 hypoconulids with our FAM, but again this is a feature shared with many adapiforms and omomyiforms and is not indicative of a special relationship between Siamopithecus and African anthro- poids. All that can be said is that the morphology present in these Southeast Asia primates would not be expected in the ancestor of the African anthropoids. However, as with Eosimias (see below), a shared common ancestry between African Fayum anthropoids and these larger-bodies Southeast Asian primates cannot be ruled out (also see Ducrocq, 1998; Jaeger et al., 1998).

\section{Asian primate radiation}

In order to assess the possible Asian origins of anthropoids, we reexamined all published evidence of Eocene fossil primates from Asia. Figure 7 shows the distribution of Asian primates through the Eocene. Figure 8 shows the results of a phylogenetic analysis of selected members of the Asian primate radiation combined with anthropoids from the Fayum. Table 5 provides a provisional classification of Asian Eocene primates, based on our interpretations of paleobiogeography and our phylogenetic analysis.

We believe that at least six different groups of primates are represented in the Eocene of Asia. Included among adapiforms are the families Sivaladapidae, represented by Hoanghonius, Rencunius, and Guangxilemur from China, and Wailekia from Thailand, and Adapidae, represented by Adapoides 

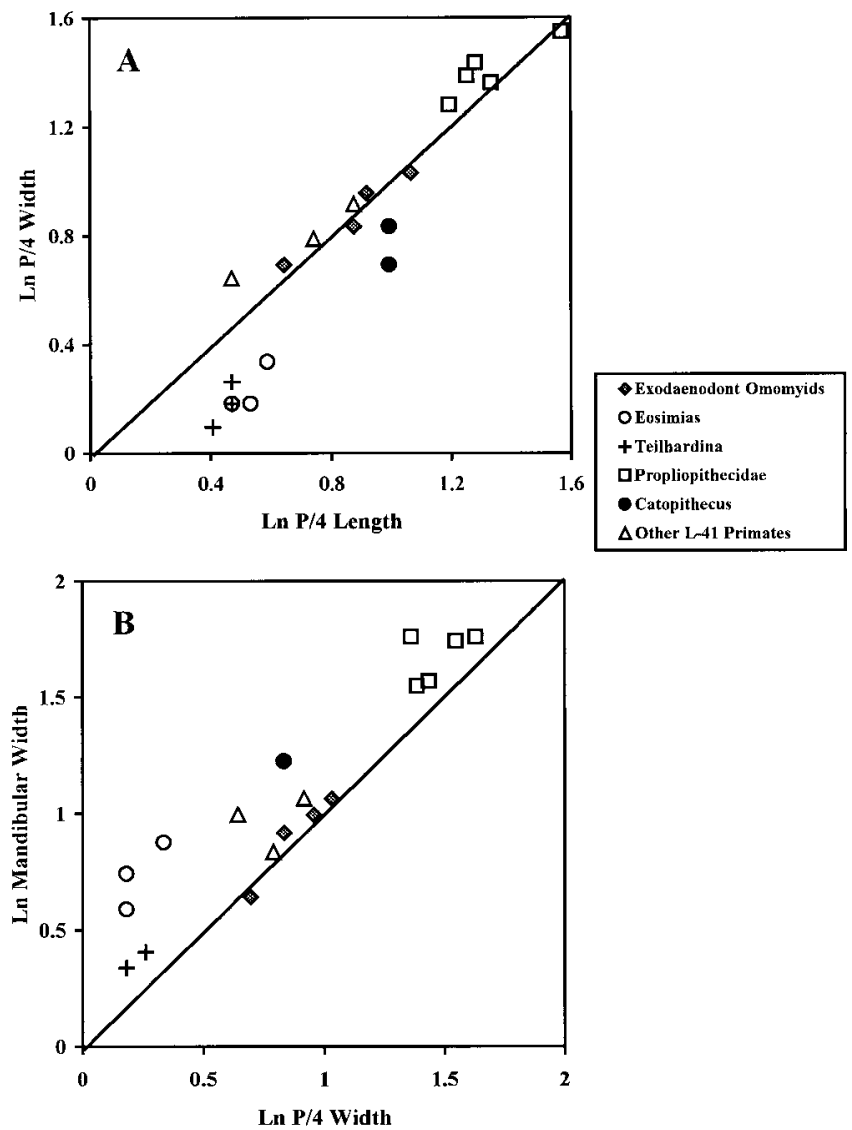

Fig. 6. Lower p4 length vs. width (A) and p4 width vs. mandibular width below p4 (B). A: Diagonal line indicates p4 as wide as long. Note that most exodaenodont omomyids and most anthropoids (except Catopithecus) fall near or above the line, indicating p4 at least as wide as long. Also note that Eosimias clusters with Teilhardina as taxa that have $\mathrm{p} 4$ longer than wide. B: Diagonal line indicates a $\mathrm{p} 4$ and mandibular horizontal ramus of the same width. Note that exodaenodont omomyids and several anthropoids cluster near line, indicating relatively wide $\mathrm{p} 4 \mathrm{~s}$. Also note that Eosimias is included among taxa with relatively narrow $\mathrm{p} 4 \mathrm{~s}$.

and a Europolemur-like taxon from Shanghuang in China (Beard et al., 1994). Other adapiforms of uncertain affinities include the enigmatic taxa Lushius from China and Panobius from Pakistan. The Eocene sivaladapid taxa share their closest affinities with the later-occurring Asian Miocene taxa Indraloris, Sivaladapis, and Sinoadapis (Gingerich et al., 1994; Qi and Beard, 1998). Adapoides and the Europolemur-like taxon are most similar to adapiforms from the Eocene of Europe and Africa (Beard et al., 1994; Simons et al., 1995; Simons, 1997a; Simons and Miller, 1997), while Lushius (Chow, 1961) and Panobius (Russell and Gingerich, 1987) are difficult to place taxonomically because they are poorly represented and differ in known morphology from more typical adapiforms.

Tarsiiforms are represented by at least two and possibly four omomyid taxa. Asiomomys and Macrotarsius are omomyines from China (Beard and Wang, 1991; Beard et al., 1994), while Kohatius

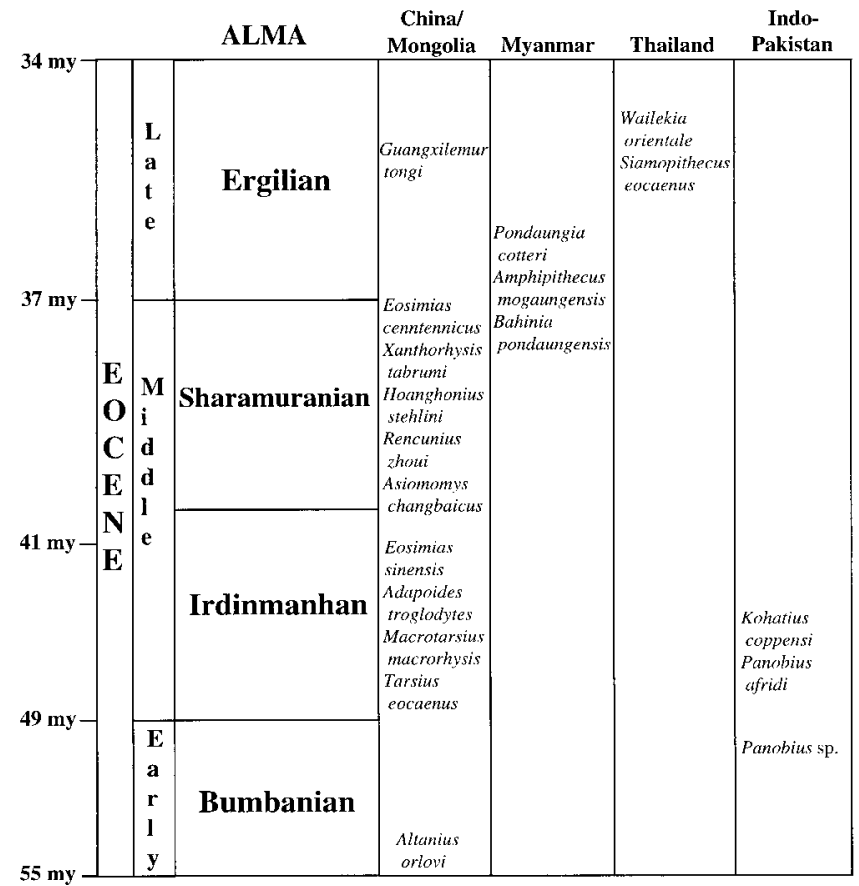

Fig. 7. Generalized stratigraphic distribution of Asian Eocene primates. Lushius and the Europolemur-like taxon are not shown, but both are known from the Sharamuranian in China. ALMA, Asian Land Mammal Age. Placement of taxa within land mammal ages does not indicate relative stratigraphic position, only that the taxon is known from that age.

from Pakistan and Altanius from Mongolia (Dashzeveg and McKenna, 1977; Russell and Gingerich, 1980) may represent omomyids as well, but their affinities are less well resolved. Unlike the adapiforms Adapoides and the Europolemur-like taxon, both of which show European and African affinities, the omomyines Asiomomys and Macrotarsius are much more closely related to North American taxa, with Asiomomys representing a form very close to Stockia (Beard and Wang, 1991), and Macrotarsius being a genus shared in common between Asia and North America (Beard et al., 1994). Kohatius is still very poorly known but appears to be quite primitive in represented morphology (Russell and Gingerich, 1980; Thewissen et al., 1997). Altanius also is very primitive, and its taxonomic affinities are not entirely clear (Dashzeveg and McKenna, 1977; Rose and Krause, 1984; Gingerich et al., 1991). Two other tarsiiforms are represented in the Eocene of China by the tarsiids Xanthorhysis (Beard, 1998b) and Tarsius (Beard et al., 1994).

The affinities of the eosimiids Eosimias (Beard et al., 1994, 1996) and Bahinia (Jaeger et al., 1999) are also difficult to assess with certainty. A phylogenetic analysis was carried out on our data matrix (Table 3), using PAUP 4.0. Our analysis, based on the limited number of dental characters used in this study, indicates that Eosimias is the sister taxon to $\mathrm{Ba}$ hinia, with the Fayum tarsiiform Afrotarsius (Simons and Bown, 1985) being the sister taxon to that clade. These relationships held constant in both of 


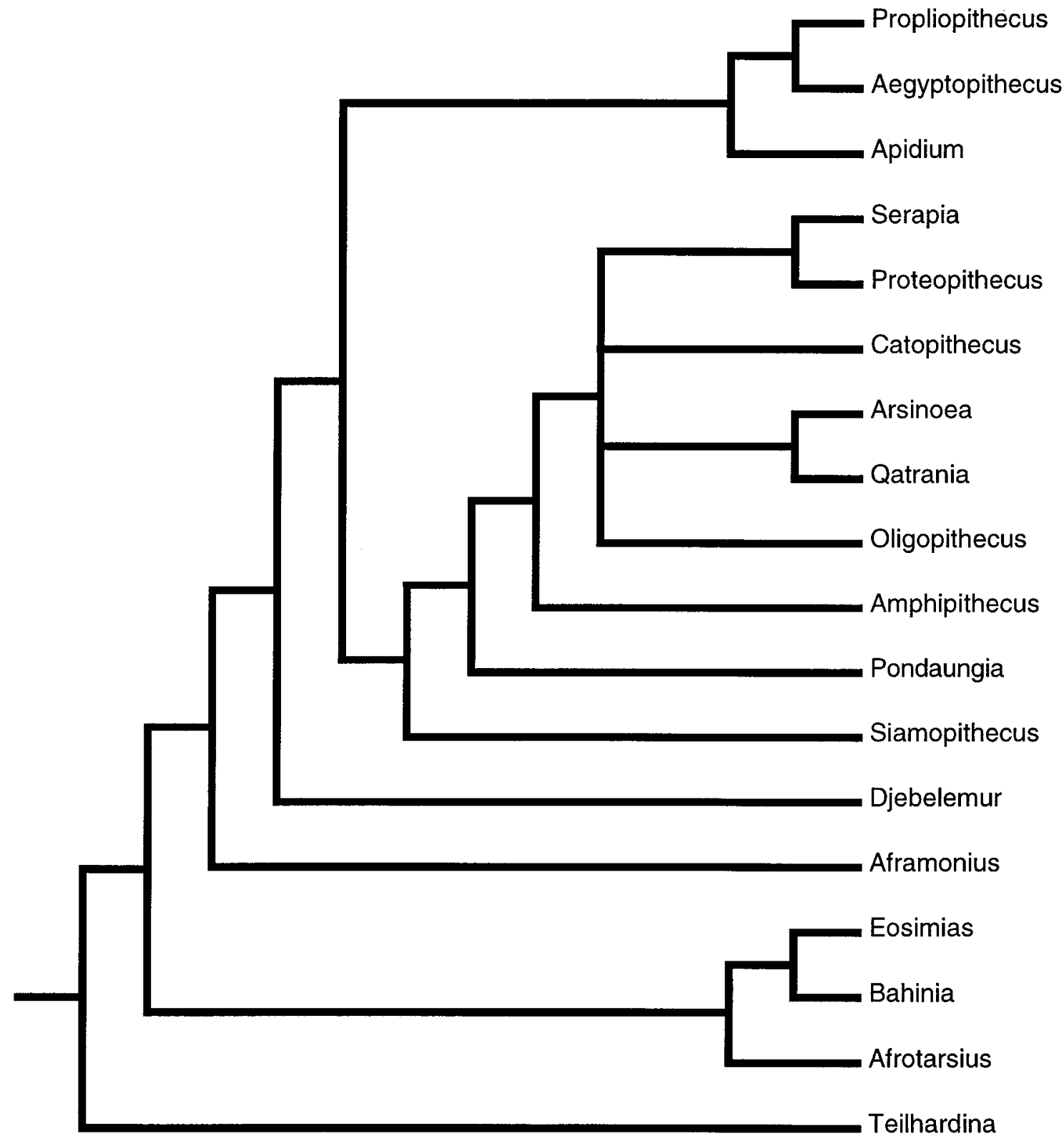

Fig. 8. Cladogram of strict consensus tree of anthropoids and related taxa generated from a PAUP 4.0 analysis of 22 characters and 18 taxa (see Tables 2 and 3). This analysis employed a random stepwise-addition heuristic search with 1,000 replications. Options included: outgroup rooting constrained to make ingroup monophyletic; Teilhardina designated as outgroup; collapse branch options was turned off; and option to start from random trees selected. Characters 1-2, 4, 8, 10-11, 13-14, 17-19, and 21 (see Table 2) were treated as ordered; all characters were equally weighted. This analysis produced two most parsimonious trees of length $=83$ steps, consistency index $=0.51$, retention index $=0.62$, and homoplasy index $=0.49$. The only instability within these trees was in the positions of Catopithecus and Oligopithecus. In the first tree, Catopithecus and Oligopithecus formed a clade that was the sister group to a pair of sister clades formed by Serapia and Proteopithecus, and Arsinoea and Qatrania. In the second tree, Catopithecus was the sister taxon to a clade formed by Serapia and Proteopithecus, with Oligopithecus as sister taxon to that clade. Arsinoea and Qatrania formed a sister group to the clade formed by the other four taxa.

our most parsimonious trees. In short, we find no strong evidence, neither in our analysis of the ancestral morphotype of Fayum anthropoids nor in our admittedly limited phylogenetic analysis of fossil anthropoids, to support a hypothesis of an ancestordescendant relationship between eosimiids and Fayum anthropoids. While our analysis did not support a direct sister group relationship between eosimiids and anthropoids, other analyses have done so, based on different lines of evidence (Beard et al., 1994, 1996; Kay et al., 1997; Jaeger et al., 1999; Gebo et al., 2000).

In general, eosimiids either: 1) have been found to be the sister taxon to tarsiiforms (either Tarsius or a combination of Tarsius and assorted omomyids; e.g., Ross et al., 1998), with this clade being the sister group to anthropoids; or 2) eosimiids are the sister group to anthropoids, with tarsiiforms being the sis- 
TABLE 5. Provisional classification of Asian early Cenozoic primates ${ }^{1}$

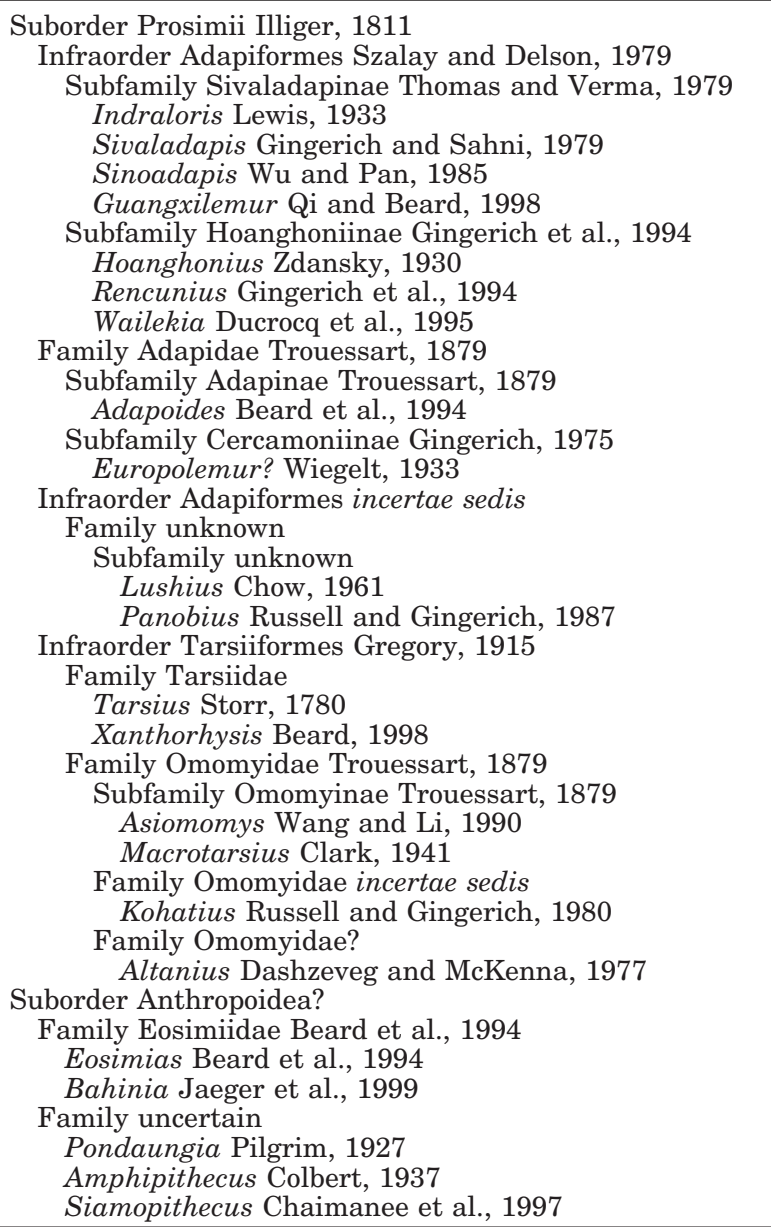

${ }^{1}$ Known from Miocene, all others from Eocene.

ter group to that clade (Kay et al., 1997; Gebo et al., 2000). Our analysis supports a relationship between eosimiids and tarsiiforms, but places this clade as the sister group to a clade formed by adapiforms and anthropoids. These different outcomes almost certainly are the result of different choices of characters, different choices in the coding of those characters, the smaller number of characters used in our analysis, and the fact that we purposely chose not to include extant taxa in our analysis. The hypotheses we set out to test concern the relationships of Fayum anthropoids to other proposed basal anthropoid taxa, not the ultimate phylogenetic or geographic origins of anthropoids; thus, our data set was more limited and focused.

\section{CONCLUSIONS}

If our reconstructed ancestral morphotype for African propliopithecids and parapithecids is a true reflection of the ancestral state for these groups, then so far no proposed basal anthropoid seems to be an appropriate candidate for ancestry of these wellknown African ones. Results of dental comparisons between African anthropoids from the Eocene and
Oligocene of the Fayum, Egypt and proposed basal anthropoid taxa from elsewhere in Africa and Asia suggest the following: 1) neither Eosimias nor the known specimens of Bahinia, Pondaungia, Amphipithecus, or Siamopithecus make these primates good candidates to be ancestral to the African propliopithecids and parapithecids; 2) all or some of these taxa may share common ancestry with African propliopithecids and parapithecids, but sister group status does not confirm nor refute possible ancestry; 3 ) at least some of these taxa (e.g., Eosimias, $\mathrm{Ba}$ hinia) may represent basal anthropoids, but our analyses suggest that even if they are accorded anthropoid status, their relationships with African anthropoids are distant at best; 4) Siamopithecus is a probable anthropoid, while Pondaungia and Amphipithecus may be, but recent evidence (Ciochon et al., unpublished findings) suggests that the affinities of these latter two genera lie elsewhere; 5) Djebelemur is not an anthropoid but a cercamoniine adapiform, as it was originally described to be, nor is it a likely candidate for ancestry to the Fayum anthropoids; 6) Algeripithecus, Tabelia, and Biretia may represent basal anthropoids, but their status cannot be confirmed, nor can their possible relationships with Fayum anthropoids be determined at this time; and 7) Altiatlasius is very primitive and possesses no derived character states in common with our reconstructed morphotype. As such, it cannot be ruled out as a possible anthropoid ancestor; but it also may represent a plesiadapiform, as Hooker et al. (1999) suggested.

The ultimate center of origin for Anthropoidea may well have been in Asia (Beard, 1998b), but at this time the fossil evidence is not in favor of this hypothesis over others, primarily because evidence that might bear on this question remains virtually unknown from nearly all of Africa before the latest Eocene. The same is true for the Para-Tethyian world prior to the late middle Eocene (Ducrocq, 1998). There is, however, a growing fossil record of anthropoid-like taxa from Asia, suggesting that this continent did play a larger role in anthropoid evolution than was previously thought. The evidence that is available to date suggests a distant phylogenetic relationship between Southeast Asian taxa and fossil anthropoids from the Fayum, and it does not allow a definitive determination of the geographic center of origin for Anthropoidea. If eosimiids are basal anthropoids, then the ultimate origin of Anthropoidea predates the middle Eocene, and we see no present evidence in the Paleocene or early Eocene of a distinct anthropoid clade from any holarctic continent. The early phylogenetic history and geographic distribution of basal anthropoids remain obscure.

\section{ACKNOWLEDGMENTS}

We thank Drs. D.T. Rasmussen and P.D. Gingerich for discussions and comments on this paper. Drs. P.D. Gingerich, E.L. Simons, K.C. Beard, and 
J.-L. Hartenberger provided casts of relevant specimens for comparative purposes. Dr. W.S. Sanders and Mr. J.I. Bloch assisted in phylogenetic analysis. Mr. J. Trapani assisted with scanning electron micrography.

\section{LITERATURE CITED}

Beard KC. 1998a. East of Eden: Asia as an important center of taxonomic origination in mammalian evolution. Bull Carnegie Mus Nat Hist 34:5-39.

Beard KC. 1998b. A new genus of Tarsiidae (Mammalia: Primates) from the middle Eocene of Shanxi Province, China, with notes on the historical biogeography of tarsiers. Bull Carnegie Mus Nat Hist 34:260-277.

Beard KC, Wang B. 1991. Phylogenetic and biogeographic significance of the tarsiiform Primate Asiomomys changbaicus from the Eocene of Jilin Province, People's Republic of China. Am J Phys Anthropol 85:159-166.

Beard KC, Qi T, Dawson MR, Wang B, Li C. 1994. A diverse new primate fauna from middle Eocene fissure-fillings in southeastern China. Nature 368:604-609.

Beard KC, Tong Y, Dawson MR, Wang J, Huang X. 1996. Earliest complete dentition of an anthropoid primate from the late middle Eocene of Shanxi Province, China. Science 272:82-85.

Bown TM, Rose KD. 1987. Patterns of dental evolution in early Eocene anaptomorphine primates (Omomyidae) from the Bighorn Basin, Wyoming. J Paleontol Paleontol Soc Mem 23:1162.

Chaimanee Y, Suteethorn V, Jaeger J-J, Ducrocq S. 1997. A new late Eocene anthropoid primate from Thailand. Nature 385: 429-431.

Chow M. 1961. A new Tarsioid primate from the Lushi Eocene, Honan. Vert Palas 5:1-5.

Ciochon RL, Savage DE, Tint T, Maw B. 1985. Anthropoid origins in Asia? New discovery of Amphipithecus from the Eocene of Burma. Science 229:756-759.

Clark J. 1941. An anaptomorphid primate from the Oligocene of Montana. J Paleontol 15:562-563.

Covert HH, Williams BA. 1991. The anterior lower dentition of Washakius insignis and adapid-anthropoidean affinities. J Hum Evol 21:463-467.

Dashzeveg D, McKenna MC. 1977. Tarsioid primate from the early Tertiary of the Mongolian People's Republic. Acta Palaeontol Pol 22:119-137.

de Bonis L, Jaeger J-J, Coiffait B, Coiffait P-E. 1988. Découverte du plus ancien primate Catarrhinien connu dans l'Éocene supérieur d'Afrique du Nord. C R Acad Sci [III] 306:929-934.

Ducrocq S. 1998. Eocene primates from Thailand: are Asian anthropoideans related to African ones? Evol Anthropol 6:97-104.

Fleagle JG. 1990. New fossil platyrrhines from the Pinturas Formation, southern Argentina. J Hum Evol 19:61-85.

Fleagle JG, Simons EL. 1982a. The humerus of Aegyptopithecus zeuxis: a primitive anthropoid. Am J Phys Anthropol 59:175193.

Fleagle JG, Simons EL. 1982b. Skeletal remains of Propliopithecus chirobates from the Egyptian Oligocene. Folia Primatol (Basel) 39:161-177.

Fleagle JG, Simons EL. 1983. The tibio-fibular articulation in Apidium phiomense, an Oligocene anthropoid. Nature 301:238-239.

Fleagle JG, Simons EL. 1995. Limb skeleton and locomotor adaptations of Apidium phiomense, an Oligocene anthropoid from Egypt. Am J Phys Anthropol 97:235-289.

Fleagle JG, Powers DW, Conroy GC, Watters JP. 1987. New fossil platyrrhines from Santa Cruz Province, Argentina. Folia Primatol (Basel) 48:65-77.

Gebo DL. 1993. Postcranial anatomy and locomotor adaptation in early African anthropoids. In: Gebo DL, editor. Postcranial adaptation in nonhuman primates. Dekalb: Northern Illinois University Press. p 220-234.
Gebo DL, Dagosto M, Beard KC, Qi T, Wang J. 2000. The oldest known anthropoid postcranial fossils and the early evolution of higher primates. Nature 404:276-278.

Gingerich PD. 1977. Dental variation in early Eocene Teilhardina belgica, with notes on the anterior dentition of some early Tarsiiformes. Folia Primatol (Basel) 28:144-153.

Gingerich PD, Dashzeveg D, Russell DE. 1991. Dentition and systematic relationships of Altanius orlovi (Mammalia, Primates) from the early Eocene of Mongolia. Geobios 24:637-646.

Gingerich PD, Holroyd PA, Ciochon RL. 1994. Rencunius zhoui, new primate from the late middle Eocene of Henan, China, and a comparison with some early Anthropoidea. In: Fleagle JG, Kay RF, editors. Anthropoid origins. New York: Plenum Press. p 163-177.

Godinot M. 1994. Early North African primates and their significance for the origin of Simiiformes (= Anthropoidea). In: Fleagle JG, Kay RF, editors. Anthropoid origins. New York: Plenum Press. p 235-295.

Godinot M, Mahboubi M. 1992. Earliest known simian primate found in Algeria. Nature 357:324-326.

Godinot M, Mahboubi M. 1994. Les petits primates simiiformes de Glib Zegdou (Éocène inférieur à moyen d'Algérie). C R Acad Sci [III] 319:357-364.

Gunnell GF. 1995. Omomyid primates (Tarsiiformes) from the Bridger Formation, middle Eocene, southern Green River Basin, Wyoming. J Hum Evol 28:147-187.

Hartenberger J-L, Marandat B. 1992. A new genus and species of an early Eocene primate from North Africa. Hum Evol 7:9-16.

Hooker JJ, Russell DE, Phélizon A. 1999. A new family of Plesiadapiformes (Mammalia) from the Old World lower Paleogene. Palaeontology 42:377-407.

Jaeger J-J, Soe UAN, Aung UAK, Benammi M, Chaimanee Y, Ducrocq R-M, Tun T, Thein UT, Ducrocq S. 1998. New Myanmar middle Eocene anthropoids. An Asian origin for catarrhines? C R Acad Sci [III] 321:953-959.

Jaeger J-J, Thein T, Benammi M, Chaimanee Y, Soe AN, Lwin T, Tun T, Wai S, Ducrocq S. 1999. A new primate from the middle Eocene of Myanmar and the Asian early origin of anthropoids. Science 286:528-530.

Kay RF, Williams BA. 1994. Dental evidence for anthropoid origins. In: Fleagle JG, Kay RF, editors. Anthropoid origins. New York: Plenum Press. p 361-445.

Kay RF, Ross C, Williams BA. 1997. Anthropoid origins. Science 275:797-804.

Miller ER, Simons EL. 1997. Dentition of Proteopithecus sylviae, an archaic anthropoid from the Fayum, Egypt. Proc Natl Acad Sci USA 94:13760-13764.

Qi T and Beard KC. 1998. Late Eocene sivaladapid primate from Guangxi Zhuang Autonomous Region, People's Republic of China. J Hum Evol 35:211-220.

Rasmussen DT, Simons EL. 1988. New specimens of Oligopithecus savagei, early Oligocene primate from the Fayum, Egypt. Folia Primatol (Basel) 51:182-208.

Rasmussen DT, EL Simons. 1992. Paleobiology of the oligopithecines, the earliest known anthropoid primates. Int J Primatol 13:477-508.

Rose KD, Krause DW. 1984. Affinities of the primate Altanius from the early Tertiary of Mongolia. J Mammal 65:721-726.

Rose KD, MacPhee RDE, Alexander JP. 1999. Skull of early Eocene Cantius abditus (Primates: Adapiformes) and its phylogenetic implications, with a reevaluation of "Hesperolemur" $a$ ctius. Am J Phys Anthropol 109:523-539.

Ross C, Williams BA, Kay RF. 1998. Phylogenetic analysis of anthropoid relationships. J Hum Evol 35:221-306.

Russell DE, Gingerich PD. 1980. Un nouveau Primate omomyide dans l'Éocène du Pakistan. C R Acad Sci [III] 291:621-624.

Russell DE, Gingerich PD. 1987. Nouveaux Primates de l'Éocène du Pakistan. C R Acad Sci [III] 304:209-214.

Seiffert ER, Simons EL, Fleagle JG. 2000. Anthropoid humeri from the late Eocene of Egypt. Proc Natl Acad Sci USA 97: 10062-10067.

Sigé B, Jaeger J-J, Sudre J, Vianey-Liaud M. 1990. Altiatlasius koulchii n. gen. et sp., primate omomyidé du Paléocène su- 
périeur du Maroc, et les origines des Euprimates. Palaeontograph Abt [A] 214:31-56.

Simons EL. 1989. Description of two genera and species of late Eocene Anthropoidea from Egypt. Proc Natl Acad Sci USA 86:9956-9960.

Simons EL. 1990. Discovery of the oldest known anthropoidean skull from the Paleogene of Egypt. Science 247:1567-1569.

Simons EL. 1992. Diversity in the early Tertiary anthropoidean radiation in Africa. Proc Natl Acad Sci USA 89: 10743-10747.

Simons EL. 1995a. Skulls and anterior teeth of Catopithecus (Primates: Anthropoidea) from the Eocene and anthropoid origins. Science 268:1885-1888.

Simons EL. 1995b. Egyptian Oligocene primates: a review. Yrbk Phys Anthropol 38:199-238.

Simons EL. 1997a. Discovery of the smallest Fayum Egyptian primates (Anchomomyini, Adapidae). Proc Natl Acad Sci USA 94:180-184.
Simons EL. 1997b. Preliminary description of the cranium of Proteopithecus sylviae, an Egyptian late Eocene anthropoidean primate. Proc Natl Acad Sci USA 94:14970-14975.

Simons EL, Bown TM. 1985. Afrotarsius chatrathi, first tarsiiform primate (? Tarsiidae) from Africa. Nature 313:475-477.

Simons EL, Miller ER. 1997. An upper dentition of Aframonius dieides (Primates) from the Fayum, Egyptian Eocene. Proc Natl Acad Sci USA 94:7993-7996.

Simons EL, Rasmussen DT. 1996. Skull of Catopithecus browni, an early Tertiary catarrhine. Am J Phys Anthropol 100:261-292.

Simons EL, Rasmussen DT, Bown TM, Chatrath PS. 1994. The Eocene origin of anthropoid primates-adaptation, evolution, and diversity. In: Fleagle JG, Kay RF, editors. Anthropoid origins. New York: Plenum Press. p 179-201.

Simons EL, Rasmussen DT, Gingerich PD. 1995. New cercamoniine adapid from Fayum, Egypt. J Hum Evol 29:577-589.

Thewissen JGM, Hussain ST, Arif M. 1997. New Kohatius (Omomyidae) from the Eocene of Pakistan. J Hum Evol 32:473-477. 